Article

\title{
“Jones-ing" for a Solution: Commercial Street Surveillance and Privacy Torts in Canada
}

\section{Stuart Hargreaves}

Faculty of Law, The Chinese University of Hong Kong, Shatin, New Territories, Hong Kong; E-Mail: stuart.hargreaves@cuhk.edu.hk

Received: 12 May 2014; in revised form: 30 June 2014 / Accepted: 1 July 2014 /

Published: 4 July 2014

\begin{abstract}
While street surveillance technologies such as Google Street View are deployed with no discriminatory intent, there is selective scrutiny applied to the published imagery by the anonymous crowd. Disproportionately directed at women and members of ethnic minority groups, this scrutiny means the social risks of street surveillance are not equal. This paper considers the possibility of invasion of privacy actions in tort brought against the commercial service provider as a possible solution. Analysis suggests that Canadian law has evolved in a way such that it is exceedingly difficult to make a claim for "privacy" in tort when the plaintiff is located in public space. This evolution exists in order to ensure that innocuous behavior not be rendered actionable. Furthermore, conceptual reasons exist to suggest that actions in tort are unlikely to be the best solution to the problems posed by commercial street surveillance. While any individual case of embarrassment or nuisance matters, broader "macro-harms" that impact entire communities reflect perhaps the most serious problem associated with the selective scrutiny of street surveillance imagery. Yet, it seems difficult to justify attaching liability for those harms to the commercial providers. While limits need to be placed on the operation of these street surveillance programmes, it is unlikely that invasion of privacy actions are the most effective way to achieve that goal.
\end{abstract}

Keywords: privacy; surveillance; tort; StreetView; Google; Ontario; Canada; law; internet

\section{Introduction}

Commercial public street surveillance, as distinct from the surveillance of private space for commercial needs (e.g., CCTV), is a growing phenomena in Canada. The best-known example is Google's expansive "Street View" project, which has digitally photographed almost all populated 
areas of Canada (indeed, of the world) and then made available those images online for "virtual exploration". While this new form of digital mapping is technologically impressive and has proved popular with many Canadians, it brings with it certain risks, driven by a form of scopophilia - the love of looking. Although the technology is facially neutral and is deployed by Google et al. without discriminatory intent, the gaze of the anonymous audience that accesses the imagery is not directed in such an equal manner. As a result, despite the benign intentions on the part of the service providers, the effects of these projects are likely to be experienced in different ways by different groups. Take, for instance, the range of third-party websites in which images deemed "notable" or "interesting" are copied from the original imagery published the commercial service providers, archived and re-posted for comment [1-3]. The individuals that participate in these online communities tend to be young, male, and digitally well-connected - and the targets of their scrutiny and subsequent commentary are predominantly drawn from racialized groups and women. Gender, ethnic, and economic biases are all revealed and reinforced by the way in which the scrutiny is applied.

In particular, the scrutiny applied to street surveillance imagery by the anonymous audience has a heavy focus on sexualized imagery of women. Images of women sunbathing [4], dressed in "revealing" clothing [5], or in swimwear [6] are particularly popular with the anonymous audience, who appear to devote considerable energies to finding such images and then rating the attractiveness of the women they feature. The website "doxyspotting.com" is perhaps the most overt example: users scour Google Street View for images of women believed to be sex workers, and then record them in a competitive fashion. The "frequently asked questions" portion of their website states:

Why spot prostitutes on Google StreetView?

Google Maps Street View is the ideal voyeuristic tool. People are voyeuristic in naturemen especially. It is very easy to spot a girl with nice big boobs on Google Street View. Spotting prostitutes may seem a bit more difficult. But if you know what to look for, it actually becomes quite easy. For example you can drop the StreetView Icon pretty much anywhere in Madrid's Zona Industrial de Villaverde and you will be able to spot a hooker on Google Street View. Doxy Spotting is almost a sport. It is the perfect and insuspicious [sic] way to kill some time at work or if you are bored. But be warned - doxy spotting is highly addictive [7].

This digital replication of the "male gaze" is by no means limited to doxyspotting.com. Across all the websites that archive images, invariably young women form a significant portion of what is deemed by the viewers to be notable or interesting, even though all they are doing is simply "existing" as women in public space. Once the images are uploaded and shared, the women tend to be the subject of sexualized commentary. The scrutiny applied to street surveillance imagery is by no means limited to this kind of sexual voyeurism, however. Images that feature members of ethnic minority groups are often selected and shared, and then interpreted by online commentators as showing criminality, despite there not being any clear criminal behaviour in the images. Other images can be best understood as examples of "poverty porn", in which assumptions about members of less well-off communities are made and the images are used for the gratification of the viewer. For instance, anonymous viewers discovered a Street View image of young black men gathered around a car, and instantly concluded that it that it revealed a "drug deal from every angle", despite a complete absence of narcotics in the 
image [8]. Similarly, another image discovered appeared to show a black man getting out of his car at a stop-light. A police car was elsewhere in the image, and the anonymous crowed instantly took this to mean that the man in the first vehicle was "getting arrested", despite absolutely no evidence to support such a claim [9]. Images of what has been termed "poverty porn" are often also frequently shared and commented upon the users of these third-party websites. In one instance, a photo of three girls outside a working-class estate in England was taken to be an example of "urban poverty, drug crime, and decay" [10], while a photo of four black men walking down the street was cited as "one of the most dangerous neighbourhoods in America" [11]. In all these cases, by being photographed in these images and associated with disparaging commentary, subjects of street surveillance are subject to the phenomena of the synecdoche - a small slice of their life is taken to represent the entirety of their being.

While in extreme cases actions in tort for harassment, nuisance, or defamation might conceivably be brought against the anonymous users that re-share, scrutinize and comment upon the imagery online, any single piece of commentary likely does not rise to this level-but the cumulative effects of the commentary are nonetheless significant. This also means that, short of outright "hate speech", actions against anonymous commentators will frequently run into (entirely legitimate) counter-balancing concerns regarding freedom of expression. Moreover, the potential for a successful action against an online harasser is greatly complicated by the fact that the putative defendant is almost certainly operating under an anonymous identity, and may not even be located in the same jurisdiction. These are not insurmountable problems, of course, but they significantly increase the costs and difficulties associated with bringing a claim against a member of the anonymous crowd, correspondingly lowering its chance of success. In this paper, therefore, I want to consider whether an alternative action brought against a well-known service provider for "invasion of privacy" would be a viable means of reducing the likelihood of serious social harms arising from the use of commercial street surveillance technologies in Canada.

This paper therefore considers the potential of bringing such an action under the statutory torts that protect privacy in several Canadian provinces (British Columbia [12], Manitoba [13], Saskatchewan [14], Newfoundland and Labrador [15]) and under the common law "intrusion upon seclusion" tort that was recently adopted in Ontario [16,17]. In either form, however, I suggest the likelihood of success remains low. The jurisprudence under the statutory torts relies upon an a priori distinction between "public" and "private" space that appears to doom any claim related to being photographed in public. While there is not yet a highly developed body of Ontario jurisprudence based on the new common law tort, the American law on which it is based may serve as a reasonable predictive guide. Under that jurisprudence, meeting the constituent elements of the tort in the context of public photography is also extremely difficult. This, though, is less a "failure" of the jurisprudence and more a necessary limitation on the scope of any privacy tort. While commercial street surveillance programmes can be understood as causing a privacy loss, that is a separate question from whether that loss ought to be actionable. A privacy tort that renders being photographed in public space actionable would likely also attach liability to a whole host of innocuous behaviour. I conclude by suggesting it may be the case that the most serious kind of harm associated with a diffuse commercial surveillance programme is not best remedied by tort law at all, since the injuries caused are not limited to just those suffered by an individual captured in a photograph and subject to unwanted scrutiny and online commentary. Rather, the selective selection of imagery for scrutiny and sharing results in broad dignitary damage to entire 
socio-economic groups, which harms all members whether or not any one individual is actually photographed or otherwise recorded by a street surveillance programme. It is these harms that are perhaps the most serious, but actions aimed at remedying discrete/isolated intrusions into personal privacy are not an effective solution to them.

\section{The Provincial Statutory Torts for Invasion of Privacy}

The contours of the four provincial statutorily-created private law actions for invasion of privacy are generally similar. The Privacy Act in British Columbia, for instance, creates a tort, "actionable without proof of damage, for a person, wilfully and without a claim of right, to violate the privacy of another" ([12], s. 1(1)). While the B.C. Act does not provide an exhaustive definition of what a violation will entail, it does note that it includes "eavesdropping and surveillance, whether or not accomplished by trespass" ([12], s. 1(4)). Individuals are deemed to be entitled to a degree of privacy that is "reasonable in the circumstances", and the "nature, incidence and occasion of the conduct in question" as well as the relationship between the parties will assist the court in determining whether a violation of that privacy has occurred ([12], s. 1(2), (3)). Statutory defences include consent; that the conduct was in the exercise of a lawful right in defence of property or person or was authorized or required by law; or that the conduct was that of a peace or public officer engaged in their official duties ([12], s. 2(2)). There is also a defence for publication of a private matter if the matter was in the public interest or fair comment on a matter within the public interest ([12], s. 2(3)). The other provincial Acts are much the same, with one notable variation being the Manitoba variant which, unlike the others, requires that there be a "substantial" violation of privacy in order to ground a claim, and also lacks the "wilful" requirement [13]. No action against a commercial street surveillance provider has been brought under any of these Acts, and so the analysis that follows will be based on other cases of surveillance, tracking, or other forms of privacy invasion that relate to the revelation of publicly available information [18].

\subsection{Wilfully}

In Peters-Brown, the plaintiff sought compensation after the defendant hospital created a list of patients around whom special precautions ought to be taken; somehow, that list ended up in the hands of her co-workers, who were led to believe she was suffering from AIDS [19]. While her claim for negligence against the hospital succeeded, her claim for invasion of privacy under the Sask. Act failed, with the court reasoning that "wilful" in the context of the Act meant an "intentional" invasion of privacy ([19], para. 35). Since the hospital had not intended that the patient information be circulated beyond the hospital staff, there could be no liability under the Act. It is true that the photography that happens to capture an identifiable individual is merely an unintended consequence of the broader project to record public space — problematic as it may be, the purpose or intent behind photography by Google Street View and similar services is not to invade individual privacy or to collection personal information, but rather to create digital maps. Thus, in some sense the invasion of privacy is collateral to this purpose. However, per Hollinsworth, the issue of intent turns not on the direct intent to invade privacy, but rather the intent to do an act that the defendant "knew or should have known would violate the privacy of another person" ([20], para. 24]. On this standard, it seems that the actions of the 
service providers can fit within the "wilful" requirement as it has previously been interpreted under the provincial Acts. A much greater challenge, however, turns on whether or not an individual in public space has a reasonable expectation of privacy.

\subsection{A Reasonable Expectation of Privacy}

On the one hand, as a practical question Google seems to accept that individuals in public places have some kind of expectation of privacy vis-à-vis being photographed — after all, Google attempts to automatically blur both faces and license plates under the guise of a "privacy protection" [21]. However, as a legal question, the answer to whether or not individuals retain an expectation of privacy is significantly different. As the jurisprudence has developed under the provincial statutory torts, the courts have placed significant importance on an initial spatial or locational question in determining the reasonableness of an individual's expectation of privacy. In circumstances where the subject is in an area typically understood as "private" and the watcher has invaded that same area in order to conduct surveillance, then the reasonable expectation of privacy afforded to the subject is considered high. Thus in cases involving sexual voyeurism [22] via hidden peepholes or cameras, courts have been quick to find that an individual's reasonable expectation of privacy has been violated, often awarding significant punitive damages [23]. In contrast, when both the subject and the watcher are in public space, the expectation of privacy of the former is deemed to be much lower. Courts have accepted that "there is no reasonable expectation of privacy for actions taking place in public" ([24], para. 77).

A person's reasonable expectation of privacy in his or her own home is ordinarily very high whereas... in a public place [it is] substantially less so... overt actions and behaviours occurring in public are not really 'private' at all ([25], para. 21).

However, when the subject of the surveillance is in an area typically understood to be private but can easily be seen from public space without special devices, the judicial calculation is slightly more complicated. For instance, where events on openly viewable private property have been recorded from the vantage point of a public street, one court found that the individuals recorded had no recourse under the British Columbia version of the tort.

The salient feature... is the location in which the filming took place. Events transpiring on this parking lot could hardly be considered private in the sense of being shielded form observation by the general public ([26], para. 17).

More surprisingly, perhaps, this logic has occasionally been extended to interiors of private homes that are viewable from the outside - in Milner it was held that while "a person's expectation of privacy [is] highest in [their] home", it was nonetheless lowered since the plaintiff had left "the blinds open and the lights [on]", meaning anyone could see her ([24], paras. 76, 83). Other decisions appear to reject this contention, however. In Wasserman, the court found that the plaintiff had a reasonable expectation of privacy in the interior of his home, even though he had initially declined to take any steps to block the view of the camera his neighbour had set up to monitor their mutual fence following a property line dispute [27]. Wasserman also held that individuals have a reasonable expectation of privacy in the immediate vicinity of their homes, even when those areas are visible to passers-by (in Wassserman, the plaintiffs were also recorded sitting on their outdoor patio, which was viewable from 
the street). This was consistent with the earlier decision of Heckert, in which the complaint related to a video camera ostensibly installed for security purposes in an apartment building [28]. The image generated by the camera showed the entire common hallway, the elevator doors, and the door to the plaintiff's unit in the immediate foreground; the images did not reveal any activities inside the unit ([28], paras. 37-39). Walker J. accepted that the plaintiff nonetheless enjoyed a reasonable expectation of privacy in the hallway, even though it was open to anyone who lived in the building and their guests and was thus a quasi-public area (or in the words of Walker J., "not truly private") ([28], para. 90).

Now, it is true that commercial street surveillance often captures images of individuals in the vicinity of their homes, and, though rarely, might also capture images of people within their homes (for instance, through a window or open door). Distinctions can still be drawn, however, between this and the way in which the "vicinity" cases operate. In both Wasserman and Heckert, the cameras used were continuously active video cameras with a relatively narrow field of vision, trained on a fixed area, located adjacent to an a priori private place. In contrast, street surveillance cameras irregularly photograph broad areas with wide-angle lenses, using still imagery rather than continuous video recording. Of course, it is possible that future versions of the service might adopt different techniques of photography, including high resolution video [29]. Indeed, there are some services that already offer such a product, though not in Canada. Recall that the Acts all note that the reasonableness of the expectation of privacy in any given situation is altered by the "nature, incidence and occasion of the conduct in question"; Heckert and Wasserman are thus probably best interpreted as edge cases related to particularly intrusive forms of surveillance of quasi-private areas. As a general rule, when an action under one of the provincial torts has been brought for a claimed violation of privacy thanks to visual surveillance, once the spatial question about the location of the claimant has been answered by the courts as being "public" or "viewable from public space without special measures", that effectively ends the chances for a successful claim. The influence of this spatial question is therefore most likely fatal to any claim brought against a commercial street surveillance provider brought under any of the provincial Acts that provide statutory protections against invasions of privacy.

\section{The New Ontario Common Law Tort for Invasion of Privacy}

Under the common law, privacy interests in Canada have historically been protected not through a distinct "privacy" tort, but rather others such as nuisance, trespass, defamation, injurious falsehood, deceit, and passing off [30]. In the 1990s and the early twenty-first century, however, the influence of s. 8 the Charter [31] began to be felt in this area, as it "underscore[d] that privacy is a societal value to be protected" ([32], pp. 226, 230). Lower courts in Ontario began mulling the protection of privacy through a specific tort more explicitly, though they continued to prefer to rely on more well-accepted torts to resolve the cases before them [33]. In Tran, however, the Superior Court of Justice reviewed a number of those early cases and suggested that together they established that an independent tort of invasion of privacy ought to be considered a "valid" cause of action in Ontario ([34], para. 38). In 2005, the Ontario Court of Appeal confronted the possibility in Euteneier [35], in which the plaintiff claimed, inter alia, that her privacy had been invaded when she was placed in a video-monitored cell and stripped of her clothing by two police officers subsequent to a (lawful) arrest and detention. The defendant police officers were successful at trial and partially successful at the divisional court. 
The cross-appeal of the plaintiff at the Court of Appeal was an argument that the trial judge erred by failing to take into account the plaintiff's privacy and dignity interests when formulating the duty of care standard to be applied. In dismissing this, the Court noted that counsel for the plaintiff "properly conceded in oral argument before this court that there is no 'free-standing' right to dignity or privacy... at common law" ([35], para. 63). They did not, however, rule that such a tort could not exist.

Released immediately on the heels of Eutenier (and so not citing it) came Somwar [36], in which the plaintiff sued a well known fast-food chain for unlawfully invading his privacy after they conducted a credit check on him without permission. The defendants brought a motion for summary dismissal, arguing that since there was no recognized tort of invasion of privacy at the common law, the plaintiff's claim disclosed no reasonable cause of action [37]. Stinson J. concluded, however, that:

The traditional torts such as nuisance, trespass, and harassment may not provide adequate protection against infringement of an individual's privacy interests. Protection of those privacy interests by providing a common law remedy for their violation would be consistent with the Charter values and an incremental revision' and logical extension of the existing jurisprudence... the time has come to recognize invasion of privacy as a tort in its own right ([36], paras 29, 31).

Somwar, though only a ruling on a motion and therefore of effectively no precedential value, was the clearest acceptance then yet made by an Ontario court of a freestanding invasion of privacy tort in the common law, and was subsequently cited with approval in two other decisions at the Superior Court of Justice [38]. This evolution appeared to culminate with the appellate decision of Jones [17], a claim relating to the improper accessing of the plaintiff's financial records by the defendant. Though they did not know one another personally, both parties worked for the Bank of Montreal and the defendant had a relationship with the plaintiff's former husband. After becoming embroiled in a financial dispute with that individual, the defendant accessed the plaintiff's financial records on at least 174 occasions over two years in an attempt to confirm that the ex-husband was in fact making child support payments to the plaintiff ([16], paras. 12-14).

After reviewing the relevant jurisprudence in both Ontario and other common law jurisdictions, and considering the impact of the Charter, Sharpe J.A. (writing for the entire court) concluded that "it [was] appropriate for [the Court of Appeal] to confirm the existence of a right of action for intrusion upon seclusion" ([17], para. 65). In recognizing this new tort, Sharpe J.A. accepted that the American four-part approach to protecting privacy found in the Second Restatement of Torts was a useful starting point:

652A General Principle.

(1) One who invades the right of privacy of another is subject to liability for the resulting harm to the interests of the other.

(2) The right of privacy is invaded by:

(a) unreasonable intrusion upon the seclusion of another; or

(b) appropriation of the other's name or likeness; or

(c) unreasonable publicity given to the other's private life; or

(d) publicity that unreasonably places the other in a false light before the public [39]. 
Sharpe J.A. suggested that the facts in Jones lent themselves to consideration under the "intrusion upon seclusion or into private affairs" branch ([16], para. 21). Much like the American approach to that branch [40], the requirements of the new action in Ontario are now (1) intentional conduct by the defendant, (2) which results in the invasion of the plaintiff's private affairs without lawful justification, and that (3) a reasonable person would consider the invasion to be highly offensive ([17], para. 71). Could a claim against a commercial street surveillance provider fit within these contours? Given the recent vintage of Jones there is not yet any jurisprudence provided more examples of how the three factors might be met, so it is difficult to know with certainty [41]. In the following section, then, I consider both the jurisprudence under the provincial torts (given the similar subject matter) and that under the American version of the tort (given the explicit way in which the new tort in Jones is modelled upon it) in an attempt to develop a predictive guide as to how each of the three requirements of the new tort might be applied.

\subsection{Intentional Conduct by the Defendant}

The service providers do not intend to actually record images of people insofar as they do not set out to photograph them - it is merely is a collateral consequence of the broader operation aimed at photographing vast areas of public space. The fact that individuals are captured in the images is neither necessary to the project nor apparently desired by the service providers. However, if the "intent" requirement under the Jones tort develops in the same way as the "wilful" requirement under statutory torts, it is probable that an action against street surveillance providers will meet the necessary standard - the surveillance project as a whole is intentional, and (assuming it can be ultimately proven that the plaintiff's privacy was invaded) so long as the hypothetical defendant knew or ought to have known that this would violate the plaintiff's privacy, then this threshold will be met. Indeed, the efforts of the service providers to electronically blur faces (though only effective roughly $90 \%$ of the time [42]) are reflective of their acceptance that public photography presents a threat to an individual's subjective sense of privacy.

Interestingly, a different approach to "intent" in the context of public photography can be found in the decision of Aubry [43], which though decided under civil law principles was cited by the Alberta Court of Queen's Bench as being "instructive" for recognizing the importance of balancing off "the mutual rights and obligations... protected by the common law and privacy legislation" ([44], para. 22). Aubry claimed her privacy was invaded after a photograph of her sitting on the steps of a building was published in magazine. While the Supreme Court of Canada accepted that this was prima facie a violation of the right to privacy protected under the Quebec Civil Code [45], they also argued that it was a right that "[came] into conflict with freedom of expression, which includes artistic expression" ([43], para. 55). In such cases, according to the majority,

[The right to free expression] prevails when a person appears in an incidental manner in a photograph of a public place - an image taken in a public place can then be regarded as an anonymous element of the scenery, even if it is technically possible to identify individuals in the photograph ([43], para. 59). 
In Aubry, it was clear that the photographer intended to capture the image of the plaintiff specifically and through his technique he ensured that she was the prime subject. This led the Court to find that the invasion of Aubry's privacy was not justified, and award her \$2000 for the loss she had suffered. If the Ontario courts look to Aubry as they develop Ontario's new "intrusion upon seclusion" tort, they may adopt a similar approach in determining the issue of intent in the context of a claim over public photography [46]. If they do so, it would appear to limit the chance of a successful claim against commercial street surveillance providers, at least in the majority of cases-street surveillance is invariably taken with a wide-angle lens, and individuals are rarely the prime focus of the image initially published by the provider. Of course, thanks to the ability to digitally crop an image, the anonymous viewers can effectively "create" a new image in which a single individual is the prime or only subject, but that cannot be connected to the initial image collection and therefore cannot necessarily be ascribed as the "intent" of the service provider. But this is not definitive, of course, and it is possible that a street surveillance image can be focused on only a single individual, without any subsequent editing. In any event, the greatest challenge under the Jones formulation in the context of public photography relates not to the question of intent, but rather to whether or not a state of seclusion actually exists to be invaded, and if so, whether or not that invasion is "highly offensive".

\subsection{Invasion of Seclusion or Private Affairs without Judicial Authorization}

The American jurisprudence indicates that "intrusions" into seclusion are not limited only to the "physical" variety, but can be "physical, electronic or mechanical" ([47], p. 349). This might include the use of parabolic microphones located in public space to record the activities of a couple in their bedroom [48], or wiretapping a telephone conversation even when the "bug" is not located within the target's private space [49]. However, much like the approach of the Canadian courts under the statutory provincial torts, the American courts have been extremely reluctant to find that any kind of privacy interest has been invaded or intruded upon when the plaintiffs themselves are in public space or otherwise easily viewable by others without special means; in general, one is not in a state of "seclusion" when in public, and therefore there is nothing to be intruded upon. In Gill, the plaintiffs sued a newspaper for intrusion upon seclusion after the paper published a photograph of them in an "affectionate pose" while at an ice-cream stand at the Los Angeles Farmers' Market ([50], para. 227). By virtue of being in public, said the court, the couple had "voluntarily exposed themselves to public gaze in a pose open to the view of any persons who might then be at or near their place of business... [and thus had] waived their right of privacy" ([50], para. 230).

A similar principle can be gleaned from the jurisprudence that surrounds the third branch of the tort-publicity given to private facts. Though not adopted in Jones, the American approach to it may nonetheless influence the development of the intrusion upon seclusion tort in Ontario, given that it requires the existence of "private facts", much the way the first branch requires an initial state of "seclusion" or "private affairs". In the Restatement's commentary on the third branch, "there is no liability for giving further publicity to what the plaintiff himself leaves open to the public eye" ([40], $\S 652 \mathrm{D}$, comment b). Thus, a dancer at a strip club whose image was broadcast as part of a news segment on a particularly notorious bar in Tennessee failed in her claim that by revealing to her unknowing friends and family that she was an exotic dancer the broadcast invaded her privacy through 
the public revelation of private facts [51]. In dismissing her appeal, the Sixth Circuit Court of Appeals did not find it necessary to make recourse to any constitutional arguments regarding freedom of the press and attempt to balance off any competing interests. Instead, the court simply concluded that since the "plaintiff's activities at the club were open to the public, [her] claim for public disclosure of private life was properly dismissed by the district court as a matter of law" ([51], p. 6). The same principle was applied to deny remedy to a plaintiff who sued private investigators for using a hidden GPS device to track his movements by car on the orders of his wife as part of their divorce proceedings [52]. The court concluded that even though the placement of the device was done without the plaintiff's knowledge, since he had never driven the car to a "secluded" location or one that was out of public view, permanent tracking of his (public) location did not amount to a violation of his privacy — no "private facts" were revealed ([52], p. 1). The general principle in the American jurisprudence regarding privacy torts (broadly, not only the third branch) is that "public matters [cannot] provide a plaintiff with a cause of action" ([53], p. 920). Given the decision in Jones to model the Ontario tort on the American framework, it seems probable (though not definitive) that this may end up the case in Ontario too.

\section{3. "Highly Offensive" to the Reasonable Person}

In Jones, Sharpe J.A. stated that conduct that would meet the "highly offensive" threshold would be that which the reasonable person could see "causing distress, humiliation, or anguish" ([17], para. 71). He went on to provide a (presumably non-exhaustive) list of examples, including intrusions into "financial or health records, sexual practices and orientation, employment, [or] diary or private correspondence" ([17], para. 72). Jones, of course, was a case regarding an informational invasion rather than a visual one, and this may account for his examples. But the American jurisprudence suggests that in visual cases, plaintiffs will struggle to establish that public photography reaches the highly offensive threshold. Indeed, the sole reported American case involving a lawsuit against Google for invasion of privacy as a result of their street surveillance programmes turned largely on this issue $[54,55]$.

After discovering photos of their residence on Google Street View despite it being at the end of a private, unpaved road, Aaron and Christine Boring filed suit claiming that Google "significantly disregarded their privacy interests" ([54], p. 699). As the Borings failed to state precisely in their brief which privacy interest (under the four-part framework) it was that was violated, the District Court reviewed the possibilities and concluded that only alternatives were "intrusion upon seclusion" or "publicity given to private life" ([54], p. 699). Under both, as now is the case in Ontario, there is a requirement that the intrusion or revelation be "highly offensive" for the claim to be made out. The court concluded that while many people might resent some of the privacy implications of Street View, only "the most exquisitely sensitive... would suffer shame or humiliation" ([54], p. 699). On appeal, the Third Circuit Court of Appeals reached the same determination with regard to both branches of the tort, finding that:

No person of ordinary sensibilities would be shamed, humiliated, or have suffered mentally as the result of a vehicle entering into his or her un-gated driveway and photographing the view from there... the alleged conduct would not be highly offensive to a person of ordinary sensibilities ([55], p. 3). 
The implication is that it is unreasonable to be highly offended by the capture of "everyday" activities that are publicly viewable. Indeed, in other cases under the intrusion upon seclusion branch of the American tort, the spatial question (the location of the surveillance) is often considered not only as relevant to whether there is a state of seclusion that can be invaded, but also as a relevant to the question of "offensiveness". This effectively privileges the spatial question in the context of photography cases, as it "counts twice" under the legal analysis - once to prove there is no invasion, and then again to prove that if there was in fact an invasion, it is not offensive. Returning to Gill, the California Supreme Court ruled that while the plaintiffs were photographed linked arm-in-arm in a fashion that might be considered an intimate gesture, revealing it in the photograph did not meet the "highly offensive" threshold, as it was the portrayal of "an incident which may be seen almost daily in ordinary life" ([50], p. 231). In so doing, the court appears to at least in part link the location of the incident and its possible offensiveness. While in Jones this issue of spatial location was not addressed since it was a question of "informational" intrusion rather than visual surveillance, given the relative closeness to which Jones already tacks towards the American tort and the importance given to spatial considerations under the prior Canadian privacy-related jurisprudence, it is probable that the questions of spatial location of the plaintiff and the question of offensiveness will ultimately be linked in Ontario too. This would seem to be a fatal blow to the chances of a successful action being brought against a commercial street surveillance provider.

In Jones, much as in Boring, the question of the offensiveness of the intrusion to the "reasonable person" serves to limit scope of the new tort by excluding from its ambit "claims from individuals who are sensitive or unusually concerned about their privacy" ([17], para. 71). But there is necessarily a difficulty in relying upon a "reasonable person" standard when the effects of street surveillance can be experienced so differently by different groups of people; it is doubtful whether a truly objective standard can be developed. I am much less likely to have my image set upon by the anonymous crowd and shared for titillation and pleasure or mockery and shame than I would if I was a young woman or member of a visible minority. Should those who feel dehumanized and objectified by this process therefore be dismissed as "unusually concerned" or "sensitive" about their privacy? I would argue not. But the problem from the perspective of a claim against a commercial service provider is that even if we could agree that most people would find the sexualized commentary or mockery "offensive", the same cannot necessarily be said for the initial image collection, upon which a successful invasion of privacy action would turn. The standard in Jones and the American jurisprudence is whether the invasion is highly offensive, and if we are considering an action against a service provider, then the invasion in question must be the initial photography. And yet, the photography at issue is by and large incredibly mundane, revealing nothing more than can be gleaned by walking down the street and observing one's surroundings. As a result, absent a societal belief that any photography in a public place is "highly offensive", this element of the new Jones tort puts another very high hurdle in front of a successful claim against the service providers for invasion of privacy.

\section{The Necessity and Difficulty of Limiting the Scope of Privacy Torts}

It seems then that the likelihood of a successful action against commercial street service providers brought under a Jones-style tort is low, thanks to the limits on the scope of the tort created by the 
court. Austin describes the judicial search for appropriate limits as "containment anxiety", in which the courts resist extension of tort protections for invasions of privacy out of a fear of unduly restricting the legitimate interests of other parties ([56], p. 3). Such resistance should not be interpreted as a failure on the part of the courts, however: a right to claim an actionable privacy interest over any activity in public would be far too broad. For instance, without limitations to its scope, a tort that captured the operation of street surveillance technologies would also capture an individual tourist taking photographs on a visit to a new city; both are based on the digital "recording" of publicly viewable spaces which incidentally records people. Clearly, this would be a draconian and unacceptable limit on the expressive rights of individuals, and explains the limits seen in this paper placed by various courts when confronted with claims for privacy interests in public space. The question is, then, whether or not it is possible to come up with other limitations than the ones adopted in Jones, such that the tort that could capture the operation of commercial street surveillance technologies, but not the camera-toting tourist. It seems unlikely. For instance, one limitation might be to only allow claims where the photography has been hidden or the subject otherwise did not consent. But adding this element of "surreptitiousness" still fails to resolve the "tourist issue" - tourists generally do not actively advertise they are taking photographs, and thus many individuals captured in their images may be unaware. Likewise, street photography for the purposes of art is common and generally unobjectionable, but often incidentally captures individuals in a streetscape image without their knowledge or consent.

Another alternative might be to acknowledge a reasonable expectation of privacy not over the image capture, but with regards to the kind of distribution of images taken of them in public. For instance, an individual might reasonably expect that only those present in the area can observe their behaviours. Widespread digital distribution changes that calculus, by potentially rendering their activities viewable by billions. A claim for a reasonable expectation of privacy in public centred around the nature of distribution can account for the fact that individuals do accept a lower expectation of privacy when in public but without eliminating that expectation entirely. But unfortunately problems still exist with this conception. Distribution of an image to an audience of millions or even billions is no longer the preserve of large corporations - the digital revolution has put the power of that technology in the hands of anyone with a camera and access to a computer. As a result, we would still find that a "distribution-focused" privacy tort would treat the tourist photographer who subsequently uploaded her images to a photo-sharing website in the same fashion as the commercial operators of street surveillance technologies. It would do the same for those who took photos of a friend's birthday party in a park and uploaded them to a Facebook account without securing the consent of every person at the party. Once again, we are unsuccessful in being able to draw the boundaries of the tort tight enough to include public street surveillance but exclude behaviours for which we do not wish to attach legal liability.

The problems go beyond protecting the tourist photographer and it easy to think of many instances in which a claim for privacy vis-à-vis being photographed in public will conflict with other no less valid rights. It is not necessary to consider them all here, but the point is simply that this struggle to limit the scope of privacy claims such that other socially-beneficial behaviour does not create valid causes of action has been faced by courts in a variety of jurisdictions. Generally, common law legal systems appear to be coalescing around "offensiveness" as the best option to limit the scope of privacy claims made in public. New Zealand, for instance, has adopted the third branch of the American tort 
and likewise has adopted the requirements that the matters not already be "public" and that the disclosure be "offensive" [57]. In Australia, the latest lower court decisions appear to have, much like Jones, accepted the first branch of the American framework into the Australian common law, along with the requirement of "high offensiveness" [58]. An outlier remains England, whose courts have largely continued to dismiss [59] the idea of introducing a freestanding privacy tort, suggesting the creation of any such action is better suited to Parliament [60]. Instead, they have been more receptive to extending protections for certain kinds of breaches that would fall under the rubric of "publicity given to private facts" by expanding the action of breach of confidence. However, they have still had to struggle with the best way in which to restrict privacy interests protected by such an action so that the claims do not serve to unduly restrict the legitimate expressive interests of others. One line of cases suggests that the former can only outweigh the latter when revealing "private" information would cause significant harm to the claimant [61]. The European Court of Human Rights has also relied upon "serious harm" as a method of limiting the scope of a claim that can be made by individuals photographed in public space who feel their privacy has been invaded [62]. Though not examples of freestanding privacy torts, Campbell [61] and Peck [62] are also instances in which courts have recognized that individuals can retain some kind of privacy interest while in public or over materials they bring into the public realm. If the Jones line of jurisprudence adopted "significant harm to the plaintiff" as a limiter in place of the intrusion being "highly offensive", could that allow the successful grounding of an action for invasion of privacy in the context of street surveillance? After all, by focusing on the issue of harm, we might avoid the problem of capturing the actions of the innocent tourist photographer within the boundaries of the tort.

On the one hand, it avoids the problem that street surveillance primarily captures the mundane aspects of life-if the issue is whether or not the intrusion causes serious harm to the subject, then it should not matter whether the intrusion is into mundane affairs or not. We are confronted, however, with the problem that even though the service providers are responsible for the intrusion through unwanted photography and this creates the potential for serious harms to later arise, the former is not the direct cause of the latter. Yet, invasion of privacy torts have always been considered a species of intentional torts - those which require a deliberate act on the part of the defendant, in contrast to negligent behaviour. It is difficult to justify an invasion of privacy action against a service provider under Jones if the jurisprudence were to evolve in a way that looked to the "serious harm" caused by the intrusion, since that harm cannot be directly tied to the actions of the service provider [63]. Thus, even though a tort that evolved in this manner would no longer capture the innocuous behaviour of the camera-toting tourist, likewise it probably no longer captures the behaviour of the commercial service provider either, thus defeating the point.

\section{The Nature of the Harm and Private Law Actions Generally}

Above, I have suggested that there are particular jurisprudential reasons that an invasion of privacy tort would struggle to account for street surveillance without also capturing innocuous or socially beneficial behaviour. In this section, I want to further suggest that there are also conceptual reasons why an action in tort, no matter how its scope is drawn, may have limited usefulness in the context of commercial street surveillance. My initial claim in this paper was that despite the benign intentions of 
the service providers, commercial street surveillance subjects women to an intense gaze for the purposes of (apparently) male sexual curiosity or gratification. Likewise, that gaze has also been directed intensely to scrutinize and bring forward for anonymous commentary the everyday activities of the poor or ethnic minorities. Experiencing such unwanted scrutiny, commentary, mockery, and shaming, are perhaps best interpreted as "micro-harms", which while undeniably problematic for the individuals concerned, nonetheless pale in comparison to the dignitary "macro-harms" suffered by entire socio-economic groups; the latter are more than the sum of the former. When an image of a woman innocently sunbathing with her friends or simply walking down the street in a revealing outfit is surreptitiously taken without her consent and shared widely online, she may legitimately feel embarrassment, anxiety, and distress. But that action also — and perhaps more damagingly - reinforces a set of acceptable behaviours and norms towards women generally; whether or not those women are ever captured by street surveillance. Normative acceptance of selective "image sharing" of (primarily) young women sends the message that it is right that they be treated objects for the sexual gratification of men, that it is normal for their bodies to exist as the subject of debate and discussion, that it is valid a woman going about her everyday business to be forced into a conversation or to otherwise be expected to account for her sexuality. Likewise, propagating a false assumption that a black man photographed talking to a police officer is being arrested is problematic not only for the individual concerned, but also for a much broader community if it feeds into stereotypes about preponderance towards criminality or social deviance. This means that the "harms" associated with commercial street surveillance are suffered by far more than those actually captured in a given image and subject to derision or mockery online.

Though these "macro harms" represent the fundamental problem with unrestricted commercial street surveillance, they do not seem amenable to remedy though actions in tort. As Solove notes, "tort law looks to isolated acts, to particular infringements and wrongs" and is therefore ill suited to remedying such complaints ([64], p. 64). It would surely be challenging to successfully argue before a court that an individual who feels a loss of dignity thanks to being a member of a group subjected to longstanding stereotypes and poor social treatment has suffered an injury that could be connected to an identifiable tortfeasor. Moreover, the diffuse (yet no less serious) harms for those not caught on camera but belonging to socio-economic groups who suffer as result of their individual members being repeatedly "targeted" by anonymous viewers for selective scrutiny simply cannot be addressed by invasion of privacy actions at all. In such cases, the necessary connection between the party responsible for the initial visual intrusion and the individual complaining of an impact on their privacy is entirely missing.

A further hurdle to any kind of private law action against street surveillance providers relates to the issue of remedies. As noted, invasion of privacy torts are intentional torts, and so the issue of remoteness would not be relevant. If causation of the claimed loss could successfully be established as a result of the intentional acts of a defendant service provider, then a damage award is likely to be the remedy. However, the quantum of such an award is likely to be minimal. Under the statutory torts, even the grossest of invasions of privacy (i.e., hidden cameras inside an individual's bedroom or bathroom) resulted in maximum awards for harm suffered at around \$50,000 (Malcolm, for instance, resulted in an award of $\$ 15,000$ for general damages and $\$ 35,000$ for punitive damages) [23]. The award in Aubry, for an invasion of privacy via photography in public that revealed no intimate or 
embarrassing behaviour, was only $\$ 2000$ - an amount described by the Supreme Court of Canada as "high", though not rising to the level of a reversible error [43]. Given this judicial history, it is safe to assume that future awards for similarly innocuous public photography will be low. If we rely on actions in tort as quasi-regulatory tools, then they must have a reasonable chance of actually altering broader corporate behaviour. Assuming for the sake of argument that all the difficulties I have identified in mounting an action under an invasion of privacy tort could be overcome, it is far from certain that an award of $\$ 2000$ would be sufficient to alter that behaviour, given the immense resources that corporations like Google and Microsoft can draw upon. It would be surprising if the threat of paying out the occasional five-figure damage award gave them significant pause in the way they operate the programmes [65]. There is, of course, also the possibility of equitable relief being obtained against the company engaged in the surveillance, if a plaintiff could demonstrate that monetary damages were inadequate for some reason, or that irreparable harm would continue. But courts might find it difficult to craft an injunction in a fashion that would not have the effect of requiring street surveillance providers to cease operations in vast geographic areas. Courts may be reluctant to take such a step, given that these are undoubtedly popular technologies and most Canadians probably do not want to see them eliminated entirely.

\section{Conclusions}

Invasion of privacy actions, whether under one of the existing statutory torts in the provinces that have them or under Ontario's new common law version, are unlikely to successfully provide a remedy for an individual photographed without their consent by a commercial service provider. In both cases, the spatial question appears to dominate the legal analysis, meaning that once someone is located in public space, they lose any reasonable expectation of privacy in terms of being photographed. Moreover, it seems difficult to draw the boundaries of the tort in a fashion that would capture commercial street surveillance without also attaching liability to socially beneficial behavior. And yet, I've argued that these technologies are something quite different than the typical kinds of "street photography" experienced in the past. By creating a virtually-explorable archive of imagery that can be viewed and shared by an anonymous audience of billions, commercial street surveillance fundamentally changes the possible exposure that someone has simply by stepping outside their door. Significantly, this increased exposure is unlikely to be felt equally - the most harmful social effects are likely to be experienced by women and minority groups. This means that while the solution is unlikely to be found in private law actions, some kind of remedy remains necessary. Future work, then, must consider the possibility of developing a regulatory framework designed specifically to govern the use of street surveillance technologies in a manner that limits their potential for creating serious social risks (particularly for women and minority groups), whilst still preserving them as useful technologies for Canadians.

\section{Acknowledgements}

The author would like to thank Lisa Austin, Trudo Lemmens, and Ariel Katz for their comments on an earlier form of these arguments, and the anonymous reviewers for their comments on the submitted draft. 


\section{Conflicts of Interest}

The author declares no conflict of interest.

\section{References and Notes}

1. See for example Google Street View World. Available online: http://google-street-view.com/ (accessed on 20 April 2014).

2. See also Street View Hacks. Available online: http://www.streetviewhacks.com/ (accessed on 20 April 2014).

3. See also Google Sightseeing. Available online: http://googlesightseeing.com/streetviews/ (accessed on 20 April 2014).

4. Half Naked Sunbathing Girls on Google Street View. Google SightSeeing. Available online: http://googlesightseeing.com/2007/05/half-naked-sunbathing-girls-on-google-street-view/ (accessed on 23 April 2014).

5. Why Blur That? StreetView Fun. Available online: http://www.streetviewfun.com/2011/whyblur-that/ (accessed on 24 April 2014).

6. Nice Bikini 3. StreetView Fun. Available online: http://www.streetviewfun.com/2013/nice-bikini3/ (accessed on 24 April 2014).

7. DoxySpotting. Available online: http://doxyspotting.com/faq/ (accessed on 20 April 2014).

8. A Drug Deal Caught From Every Angle. Gawker. Available online: http://gawker.com/5004469/ a-drug-deal-caught-from-every-angle (accessed on 24 April 2014).

9. Priceless: Getting Arrested on Street View. Google Street View World. Available online: http://google-street-view.com/getting-arrested-on-google-street-view-priceless/ (accessed on 20 April 2014).

10. The Bad Part of Town. Vice. Available online: http://www.vice.com/en_uk/read/the-bad-part-oftown (accessed on 24 April 2014).

11. Top 25 Most Dangerous Neigborhoods in America. Google Street View World. Available online: http://google-street-view.com/top-25-most-dangerous-neighborhoods-in-america (accessed on 24 April 2014).

12. The Privacy Act, RSBC 1996, c 373 (effective date: 1996). Interestingly, the overwhelming majority of surveillance cases both in and out of the employment context come from British Columbia. Whether this is due to it being the jurisdiction with the first Privacy Act is unclear, but it may be the case that British Columbia is something of a test-bed for privacy actions.

13. The Privacy Act, CCSM c P125 (effective date: 2008).

14. The Privacy Act, RSS 1978, Chapter P-24 (effective date: 1978).

15. The Privacy Act, RSNL 1990, Chapter P-22 (effective date: 1990).

16. Jones $v$ Tsige, [2011] OJ No. 1273 (Ont SCJ) ('Jones trial').

17. Jones $v$ Tsige, [2012] OJ No. 148 (Ont CA) ('Jones appeal').

18. An exception will be cases that relate to employer surveillance of employees, which I have excluded from my analysis. While these cases are interesting, the balancing off of legitimate employer interests in security on their property suggests different calculations than the balancing that occurs in public spaces or private spaces monitored from public vantage points. See for 
instance Communications, Energy, and Paperworkers's Union of Canada, Local 433 v Unisource Canada, Ltd., [2004] BCJ No. 1261, Richardson v Davis Wire Industries, Ltd, [1997] BCJ No. 937, Doman Forest Products Ltd. v International Woodworkers, Local 1-357, [1990] BCCAAA No. 401, St. Mary's Hospital and H.E.U. (Re), [1997] BCCAAA No. 855, and Steels Industrial Products v Teamsters, Local 213 [1991] BCCAAA No. 500.

19. Peters-Brown v Regina District Hospital Board, [1995] SJ No. 609 (Sask. Ct. of Q.B.), aff'd [1996] SJ No. 761 (Sask. C.A.) ('Peters-Brown').

20. Hollinsworth v. BCTV, [1998] BCJ No. 2451 (B.C.C.A.)

21. See Street View Privacy. Google. Available online: http://www.google.com/maps/about/behindthe-scenes/streetview/privacy/\#streetview (accessed on 19 June 2014).

22. Sexual voyeurism was not criminalized in the Criminal Code of Canada until 2005, leaving civil remedies as the primary recourse for victims until that time.

23. See for instance Lee v Jacobson, [1992] BCJ No. 132 (BCSC) ('Lee'), reversed however on the ground it could not be established who had made the peephole used to view the sexual activity of the plaintiffs [1994] BCJ No. 2459 (BCCA), Malcolm v Fleming, [2000] BCJ No. 2400 (BCSC) ('Malcolm') (\$15,000 in compensatory damages and $\$ 35,000$ in punitive damages awarded to a woman who discovered a video camera placed in her bedroom by her landlord), LAM $v J E L I$, [2008] BCJ No. 1612 (BCSC) (' $L A M$ ') (invasion of privacy found after a woman discovered her former partner had made recordings of their sexual activity without consent along with recording images of her daughter changing clothes).

24. Milner v Manufacturer's Life Insurance Co. (c.o.b. Manulife Financial), [2005] BCJ No. 2632 (BCSC) ('Milner').

25. Druken v RG Fewer \& Associates, Inc. [1998] NJ No. 312 (NfldSCTD) (Druken) (obiter).

26. Silber (cob Stacey's Furniture World) v British Columbia Television Broadcasting System, Ltd., [1985] BCJ No. 3012 (BCSC).

27. Wasserman v Hall, [2009] BCJ No. 1932 (BCSC) ('Wasserman').

28. Heckert v 5470 Investments Ltd., [2008] BCJ No. 1854 (BCSC) ('Heckert').

29. See, for instance, Video StreetView. Available online: http://videostreetview.com (accessed on 30 June 2014).

30. See for instance Motherwell v Motherwell, [1976] AJ No. 555 (Alta CA) ('Motherwell'), at paras 24-27 in relation to repeated harassing telephone calls; the court relied on the tort of nuisance in order to arrive at a remedy rather than considering it to be a privacy violation. See also Krouse v Chrysler Canada, Ltd., [1972] 2 OR 133-154 (Ont HCJ) ('Krouse'), rev'd [1973] OJ No. 2157 (Ont CA), involving claims regarding the use of a professional football player's image for commercial purposes without his consent. The plaintiff had argued that in addition to misappropriation of his image, breach of confidence, breach of contract, and unjust enrichment, this was also an invasion of his privacy. Haines J. concluded that the issue before him could be adequately resolved on the basis of misappropriation of personality and passing off.

31. Section 8 of the Charter of Rights \& Freedoms, being Schedule B to the Canada Act 1982 (UK), 1982 c. 11 provides protections against unreasonable search and seizure. In Hunter $v$ Southam, Inc., [1984] 2 SCR 145 ('Hunter') Dickson J. (as he then was) acknowledged that the purpose of s. 8 went "at least as far" as the protection of privacy for the individual (p. 159). Subsequently, La 
Forest J. argued in $R v$ Dyment, [1988] 2 SCR 417 that privacy "is at the heart of liberty in a modern state" and that it is "grounded a man's physical and moral autonomy, [and therefore] is essential for the well-being of the individual" (at para. 427).

32. Robyn M. Ryan Bell. "Tort of Invasion of Privacy." In Annual Review of Civil Litigation 2004. Edited by Todd Archibald and Michael Cochrane. Toronto: Thomson Canada Ltd., 2005.

33. See Palad v Pantaleon, [1989] OJ No. 985 (Ont Dist Ct) ('Palad') and Roth v Roth, [1991] OJ No. 1301 (Ont Ct (Gen Div)) ('Roth'), in which Mandel J. advanced a conception of what a tort of invasion of privacy might look like, though still accepted that the cases before him could be solved through reference to existing torts. See also instance Ontario (Attorney General) $v$ Dieleman, [1994] OJ No. 1864 (Ont CJ (Gen Div) ('Dieleman'), in which the court concluded (in an interlocutory motion to restrain picketers outside the homes and workplaces of abortion service providers) that while the medical personnel had suffered an invasion of privacy, this was best seen as significant element of nuisance rather than a freestanding tort; Lipiec v Borsa, [1996] OJ No. 3819 (Ont CJ (Gen Div)), in which the court found that videotaping a neighbour's backyard in order to record on-going construction work was an "invasion of privacy", but again treated that invasion as a species of nuisance and trespass, rather than as a freestanding tort. See also Haskett $v$ Trans Union of Canada Co., [2001] OJ No. 4949, in which the court held that "one cannot assert with confidence that there is clear recognition by the Canadian common law of tort of the invasion of privacy as a discrete tort", and instead characterized the plaintiff's complaints as an allegation of negligence for breach of duty of care by the defendants (at paras 41, 49); Warman $v$ Grosvenor, [2008] OJ No. 4462 (Ont SCJ) ('Warman'), in which the court concluded the plaintiff had failed to demonstrate how the harm he suffered from an alleged privacy invasion (the publishing online of personal information and a map of his house) was distinct from the tortious conduct that grounded his valid claims of defamation and assault (at paras. 67-70).

34. Tran v Financial Debt Recovery Ltd., [2000] OJ No. 4293 (Ont SCJ) ('Tran'). Tran was reversed by the Divisional Court though not on the invasion of privacy ground, instead finding that Malloy J. had improperly interfered by assisting the unrepresented plaintiff in presenting his case, [2001] OJ No. 4103 (Ont SCJ (Div Ct)).

35. Euteneier v. Lee, [2005] O.J. No. 3896 (Ont. C.A.) ('Euteneier').

36. Somwar v McDonald's Restaurants of Canada, Ltd., [2006] OJ No. 64 (Ont SCJ) ('Somwar').

37. See Rules of Civil Procedure, R.R.O. 1990, Reg. 194, R. 21.01(1)(b).

38. See Nitsopoulos $v$ Wong, [2008] OJ No. 3498 (Ont SCJ) ('Nitsopoulos'), in which the court considered a motion to strike by the defendant on the grounds that the plaintiff's claim of invasion of privacy (as the result of a newspaper exposé in which the defendant journalist had posed as a housekeeper in the plaintiff's house) was in fact one of defamation or that it disclosed no reasonable cause of action. In dismissing the motion, Aston J. found that the invasion in question ought to be treated as 'intrusion into the seclusion and private affairs of the individual', and that it stood separately from a tort of deceit or defamation. See also Caltagirone v Scozzari-Cloutier, [2007] OJ No. 4003 (Ont SCJ_Small Claims Court) ('Caltagirone'), in which the plaintiff sued his aunt for invasion of privacy after she disclosed his HIV status to his mother.

39. Restatement (Second) of Torts, $\S 652$ A (1977). In the American legal system, "Restatements" of law such as these are not binding in the manner of statutes, but are frequently treated as 
authoritative sources of law and are regularly cited by the courts; a Restatement is effectively a quasi-codification of the common law. That said, while Restatements are strongly authoritative, this 'quasi' element should not be discounted; being the domain of state law, not all American states have accepted all four elements into their respective common laws. This four-part framework was based largely on Prosser's analysis of the American common law. See William L. Prosser. "Privacy [a Legal Analysis]." In Philosophical Dimensions of Privacy: An Anthology. Edited by Ferdinand David Schoeman. New York: Cambridge University Press, 1984, pp. 104-55.

40. "One who intentionally intrudes, physically or otherwise, upon the solitude or seclusion of another or his private affairs or concerns, is subject to liability to the other for invasion of his privacy, if the intrusion would be highly offensive to a reasonable person", Restatement (Second) of Torts, § 652B (1977).

41. In June 2014, the Ontario Superior Court considered the application of Jones in Evans v. Bank of Nova Scotia, 2014 ONSC 2135. Evans was a certification motion for a class action brought against the defendant bank, whose employee (Wilson) had admitted to improperly accessing the financial records of the plaintiffs and providing them to his girlfriend, who then passed the information along to third parties. The plaintiff alleged, inter alia, that this was an invasion of their seclusion' along the grounds of the Jones tort. In approving the certification of the class, the court accepted that the intrusion on seclusion tort as outlined in Jones was settled law in Ontario, though noted that until addressed by the Supreme Court of Canada, it was not settled law elsewhere in Canada (at para. 26). In choosing to certify the class, it was unnecessary for the Superior Court to expand upon or depart from the structure of the tort as laid down in Jones, or provide any further guidance as to its ambit. However, given that the facts leading to the claimed intrusion in both Jones and Evans are extremely similar (improper accessing of financial information), it is unlikely that as the case progresses the Superior Court will have any need to depart meaningfully from the tests laid out by Sharpe J.A.

42. Andrea Frome, German Cheung, Ahmad Abdulkader, Marco Zennaro, Bo Wu, Alessandro Bissacco, Hartwig Adam, Hartmut Neven, and Luc Vincent. "Large-Scale Privacy Protection in Google Street View." Paper presented at IEEE 12th International Conference on Computer Vision, Kyoto, Japan, 2009.

43. Aubry v Editions Vice-Versa, [1998] 1 SCR 591 ('Aubry’).

44. Sale v Barr, [2003] AJ No. 595 (Alta QB).

45. The Civil Code of Quebec, LRQ c C-1991, Art. 35: "Everyone has the right to the respect of his reputation and privacy. No one may invade the privacy of a person without the consent of the person unless authorized by law."

46. It should be noted that there is no evidence to suggest that Aubry has had any profound impact on the evolution of invasion of privacy actions outside Quebec in the years since 1998, and so no reason to think it necessarily will have any in the future.

47. Brian Kane. "Balancing Anonymity, Popularity, \& Micro-Celebrity: The Crossroads of Social Networking \& Privacy.” Albany Law Journal of Science \& Technology 20 (2010): 327-64.

48. Hamberger v Eastman, 106 NH 107 (NH Supreme Court) 1964 (Hamberger).

49. Nader v Gen. Motors Corp., 25 NY 2d 560 (NY Court of Appeals) 1970 (Nader).

50. Gill v Hearst Publishing Co., 40 Cal. 2d 224 (Cali SC) 1953 (Gill), at 227. 
51. Puckett v American Broadcasting Companies Inc., 917 F 2d 1305 (US Court of Appeals, Sixth Circuit) (1990) ('Puckett').

52. Villanova v Innovative Investigative Solutions, Inc. No. A-0654-10T2 (Superior Court of New Jersey_Appellate Division), unreported, 7 July 2011.

53. Lior Strahilevitz. "A Social Networks Theory of Privacy." University of Chicago Law Review 72 (2005): 919-88.

54. Boring v Google, Inc. 598 F Supp 2d 695, US District Ct, WD Penn (2009).

55. Boring $v$ Google Inc., No. 09-2350 US Court of Appeals, Third Circuit (2010).

56. Lisa Austin. "Privacy and Private Law: The Dilemma of Justification." McGill Law Journal 55 (2010): 1-42.

57. Hosking \& Hosking $v$ Simon Runting \& Anor, [2004] NZCA 34 (NZ Ct of Appeal) ('Hosking'). The plaintiffs (a New Zealand 'celebrity couple') sought to restrain the publication of photographs of the wife and their 18 month old twins taken without their knowledge while in public. The New Zealand Court of Appeal concluded that the time had come to "describe the cause of action as what it truly is"-protection against an invasion of privacy (at para. 110). The tort they were concerned with, therefore, fell strictly into the third category of the American framework; the court explicitly identified this similarity (at para. 118). The reliance on the American approach was notable - the Court found that "the photographs taken... [did] not disclose anything more than could have been observed by any member of the public in Newmarket on that particular day" and therefore publication would not reveal "any fact in respect of which there could be a reasonable expectation of privacy" (at para. 164). While given this first conclusion it was not strictly necessary to detail the second element of the tort, the Court nonetheless went on to conclude that "we cannot see any real harm [in the publishing of the photos]", and thus such publishing would not "be offensive to the ordinary people" (at para. 165).

58. This is a recent development. Previously, in Australian Broadcasting Co. v Lenah Game Meats, [2001] HCA 63 ('Lenah Game Meats'), the High Court declined to recognize a tort of invasion of privacy (instead accepting that breach of confidence was sufficient to protect private information if the disclosure of the information was "highly offensive to a person of reasonable sensibilities"). However, Court also held that this did not necessarily eliminate the possibility that such a tort could one day emerge in the Australian common law (at para. 132). In a subsequent lower court case Grosse v. Purvis, [2003] QDC 151 (District Ct. of Queensland) ('Grosse') the plaintiff brought an action for invasion of privacy after being stalked and harassed by the defendant. Skoien J. determined that since the High Court had not foreclosed the development of a freestanding privacy tort, he was free to do so, describing it as a "bold... [but] logical and desirable step" to take (at para. 442). Skoien J. concluded that to be actionable, an invasion of privacy would have to a willed act that invaded upon the seclusion or solitude of the plaintiff causing detriment or distress, and the invasion would also have to be undertaken "in a manner which would be considered highly offensive to a reasonable person of ordinary sensibilities" (at para. 444). However, much like the Canadian jurisprudence, the lower court decisions are mixed: see for instance Giller v. Procopets, [2004] VSC 113 (Sup. Ct. of Victoria) and Kalaba v. Commonwealth, [2004] FCAFC 326 (Fed. Ct.), in which both courts declined to proceed any further than Lenah Game Meats' contention that a tort of invasion of privacy may one day emerge. 
59. For more see Douglas \& Ors v. Hello Ltd. \& Ors, [2005] EWCA Civ 595 (in which a celebrity couple were awarded damages for having surreptitiously-taken photographs of their wedding published despite the fact that they had agreed to publish different photos from their wedding), Venables and Thompson v. New Group Newspapers, Ltd and Ors, [2001] Fam 430 (in which injunctions were granted regarding the disclosure of information that could lead to the identification of the killers of a child after they reached the age of majority and were released from prison), Theakston $v$ MGN, [2002] EWHC 137 (in which an injunction was granted preventing publication of photographs revealing a children's television presenter engaged in sexual conduct in brothel), A. v. B., [2003] QB 195 and CTB v News Group Newspapers, Ltd., [2011] EWHC 1232 (Q.B.) (both of which involved an injunction was granted preventing a newspaper from publishing the details of each claimant's sexual relationship with a woman to whom he was not married).

60. Wainwright v. Home Office, [2003] UKHL 53 ('Wainwright').

61. Campbell v Mirror Group Newspapers, Ltd, [2004] UKHL 22 ('Campbell'). In Campbell, a well-known model brought suit for invasion of privacy after a tabloid newspaper published photographs of her leaving a Narcotics Anonymous meeting. With the exception of Lord Nicholls in dissent, the Lords rejected the idea of adopting a freestanding invasion of privacy action in tort, instead framing the central dispute as whether "there was a public interest in [the Mirror's] publication of information about Ms. Campbell which it would not been justified in publishing about someone else" due to the claimant's notoriety and repeated statements to the media that she did not use drugs (at para. 57) The question was whether the newspaper owed a duty of confidence with regard to the information (the photographs and details of Campbell's treatment), and if so, was the claimant's right to privacy under Article 8 of the ECHR outweighed by the newspaper's competing right to free expression under Article 10? (Prior to Campbell, the European Commission on Human Rights had agreed with the submission of the UK government that their obligations to respect Art. 8 privacy rights under the Convention could be met with judicial recognition of an expanded breach of confidence action, and they were not required to adopt additional statutory privacy protections or judicially recognize a freestanding privacy tort in the common law. See Earl Spencer v. United Kingdom, [1998] 25 EHRR CD 105, p. 19.) Of the three sets of reasons that formed the majority in Campbell, only Lord Hope seemed to accept that a breach of confidence action could be sued to protect expectations of privacy where the information disclosed would be highly offensive. Somewhat curiously though, Lord Hope also declared that the offensiveness threshold test is only needed where the "information is [not] obviously private", which seemed somewhat tautological (at paras. 93-96). Lady Hale, in contrast, suggested that while public activities typically could not attract a privacy interest, an exception existed where further dissemination of those activities could cause significant harm to the claimant (in this case that the claimant might cease an important drug treatment programme) (at paras. 154-55). Likewise, Lord Carswell focused on whether the publication of the details of story would cause "substantial distress" (at para. 169).

62. See Peck v United Kingdom, Application no 44647/98, ECHR (4th Section), 28/04/2003 ('Peck') in which a municipal CCTV camera filmed the applicant during the beginnings of a suicide attempt. The municipality later released the CCTV footage to the media, resulting in still photos 
of the event appearing in newspapers and video footage being broadcast on a programme known as 'Crime Beat' (at paras 13-15). The applicant contended before the ECHR that the disclosure of the footage by the municipality was in violation of his Article 8 right to privacy (at para. 52). The ECHR held that there is a "zone of interaction of a person with others, even in a public context, which may fall within the scope of "private life" (emphasis mine, at para. 57). While it was true that the applicant was in a public space and did not attempt to hide himself from the cameras or from passers-by, the disclosure of the footage meant his suicide attempt "was viewed to an extent which far exceeded any exposure to a passer-by or to security observation that which the applicant could have possibly foreseen" (at para. 62). Ultimately, the ECHR awarded the applicant 11,800 euros for the non-pecuniary damage associated with the invasion of privacy he suffered, which they deemed to include significant distress, embarrassment, and frustration (at paras. 119-20).

63. This may raise the possibility of the application of contributory liability. In the context of US copyright law, contributory or secondary liability holds that a third party may be liable for a harm that they themselves did not cause, if they enabled the harm to occur or benefitted from its occurrence (see for instance Gershwin Publishing Corp. v Columbia Artists Management, $443 \mathrm{~F}$ 2d 1159 (2d Circuit 1971), in which the court ruled that "one who, with knowledge of the infringing activity induces, causes, or materially contributes... may be held liable as a contributory infringer" (at para. 8)). If such a principle were extended to Canadian tort law beyond the intellectual property context, one might envision Google or another commercial street surveillance provider being held partially liable for the acts of the infringers. However, the American jurisprudence also indicates that contributory infringement will not be found if the product in question that has led to the primary infringement (again, in the case of copyright) is "widely used for legitimate, unobjectionable purposes" (see Sony Corp v Universal Studios, 464 US 417 (1984); this case involved allegations that Sony, as a manufacturer of the Betamax video recording system, had helped contribute to the infringement of Universal Studio's intellectual property via making it easy for home users to duplicate movies. The court found that simply because it was possible that Betamax could be used for copyright infringement could not justify a finding of secondary infringement upon Sony (at para. 45). If this same principle were extended to non-copyright claims, then it would appear likely that street surveillance providers could rely upon it to avoid any kind of secondary infringement claim- "Street View" and its competitors have, after all, wide and varied uses most of which are not harmful.

64. Daniel J. Solove. The Digital Person: Technology and Privacy in the Information Age. New York: New York University Press, 2004.

65. Of course, it is also possible that repeated successful actions, even if the damages awarded were comparatively minor, might generate enough bad publicity for geo-immersive technology providers that their behavior would be altered; it is difficult to predict with any certainty. Damage awards would also be increased (in an absolute sense) if a successful class action could be mounted; however the success of such an action is not any more likely than a successful standalone case.

(C) 2014 by the author; licensee MDPI, Basel, Switzerland. This article is an open access article distributed under the terms and conditions of the Creative Commons Attribution license (http://creativecommons.org/licenses/by/3.0/). 